\title{
THE SEA BASSES Diplectrum formosum AND D. radiale (SERRANIDAE) AS FOLLOWERS OF THE SEA STAR Luidia senegalensis (ASTEROIDEA) IN SOUTHEASTERN BRAZIL
}

\author{
GIBRAN, F. Z. \\ Laboratório de Ictiologia de Ribeirão Preto (LIRP), Departamento de Biologia, FFCLRP, \\ Universidade de São Paulo, Av. Bandeirantes, 3900, CEP 14040-901, Ribeirão Preto, São Paulo, Brazil \\ Correspondence to: Fernando Z. Gibran, Laboratório de Ictiologia de Ribeirão Preto (LIRP), Departamento de \\ Biologia, FFCLRP, Universidade de São Paulo, Av. Bandeirantes, 3900, CEP 14040-901, Ribeirão Preto, \\ São Paulo, Brazil, e-mail: fergibran@hotmail.com \\ Received October 15, 2001 - Accepted March 5, 2002 - Distributed November 30, 2002
}

(With 1 figure)

\begin{abstract}
This paper reports on Luidia senegalensis being followed by Diplectrum formosum and D. radiale in shallow soft bottoms of southeastern Brazilian coast, and comments on this association between bottom-dwelling organisms and serranids. Following is likely due to the serranid's inquisitive behaviour, and both juvenile and adult sea basses acted as followers, feeding on disturbed or exposed prey due to sea star activities.
\end{abstract}

Key words: feeding association, following behaviour, sand perch, aquavina, nine-armed sea star.

\section{RESUMO}

Os micholes-da-areia Diplectrum formosum e D. radiale (Serranidae) atuando como seguidores da estrela-do-mar Luidia senegalensis (Asteroidea) no Sudeste do Brasil

Neste trabalho é descrita Luidia senegalensis sendo seguida por Diplectrum formosum e D. radiale em substratos areno-lodosos de águas rasas da costa sudeste do Brasil, com comentários sobre a associação entre organismos bentônicos e serranídeos. O comportamento de seguir organismos fossadores parece ser derivado do comportamento inquisitivo encontrado nos serranídeos, e tanto os micholes-da-areia jovens quanto os adultos foram observados atuando como seguidores, tendo se alimentado de presas perturbadas ou expostas em decorrência das atividades da estrela-do-mar.

Palavras-chave: associação alimentar, comportamento de seguir, michole-da-areia, estrela-do-mar.

Following behaviour is a diurnal association among predators and involves a nuclear species that disturbs or explores the substrate, thus attracting generalist or opportunistic fishes, the followers, which feed on prey not targeted by the nuclear ones (see Strand, 1988, and references therein). Following is a widely distributed association that probably does not negatively affect the nuclear species and, on the other hand, benefits the followers, which thus gain access to otherwise unavailable prey (Karplus, 1978; Dubin, 1982; Diamant \& Shpigel, 1985).
During $60 \mathrm{~h}$ of SCUBA at São Sebastião Channel, São Paulo coast, southeastern Brazil (see Gibran \& Castro, 1999 for description, coordinates and reference map), at depths up to $10 \mathrm{~m}$ (average horizontal visibility of $2 \mathrm{~m}$ ), from January 1999 to February 2000 (seven bimonthly 10 day trips), in four occasions, the nine-armed sea star, Luidia senegalensis (Asteroidea), was recorded being followed by the sand perch, Diplectrum formosum, and the aquavina, $D$. radiale (Serranidae), in two poorly know habitats: shallow sand and sandy mud bottoms (but see Hobson \& Chess, 1986; 
Zahorcsak et al., 2000). It is the first record of serranine sea basses following a sea star.

This association was recorded and photographed in March and November 1999, and February 2000, during 320 min of SCUBA over four days. On 22 March 1999, an individual of $L$. senegalensis was stationary and semi-buried into the mud during the afternoon, while a group of juvenile $D$. formosum (about 50-80 mm standard length, SL) was searching for and preying on small crustaceans at the bottom and in the water column nearby. When the sea star started to move, six of the sand perches (about $50 \mathrm{~mm} \mathrm{SL}$ ) were promptly attracted to it and began to inspect and pick potential prey disturbed or exposed by the sea star activity. Some of these followers were already surrounding the sea star before it started to move.

On 23 November 1999, at the same dive point but at sunset, there were several individuals of $L$. senegalensis in the open, and an adult (about 150 mm SL) "sit-and-wait" hunting individual of $D$. radiale (see Sazima, 1986, for description of this feeding tactic), was attracted to a moving sea star individual, which it followed for up to $10 \mathrm{~s}$, when it finished following and hid in a small depression on the bottom, keeping stationary and quiescent. It was nighttime already, and sand perches are diurnal and crepuscular predators (pers. obs.).

In two additional occasions, on 28 and 29 February 2000, this association was recorded at daytime. In one of these occasions, at the same dive point as the 1999 dives, a small individual of $D$. radiale (about $30 \mathrm{~mm} \mathrm{SL}$ ) was positioned in the water column, about $3 \mathrm{~cm}$ above and near the arms of a L. senegalensis individual in the open.

In the fourth observation, during a dive session over a sandy/gravel bottom, there were about 25 foraging individuals of $D$. formosum (six adults with about $130 \mathrm{~mm}$ SL, and 19 juveniles with 50-130 mm SL), within an area of about 1.5 $\mathrm{m}$ radius, together with juvenile grunts (Haemulidae) (up to $100 \mathrm{~mm}$ total length, TL). One of the D. formosum juveniles was resting over a buried sea star, touching it with its pelvic fins and tail. Some of the sand perches were attracted by another foraging sea star, semi buried, which was starting to move, and soon, all the sand perches and grunts approached the sea star (Fig. 1). Two adult $D$. formosum bit the sea star's aboral surface, which kept moving, and after that I intervened, turning the sea star and exposing its oral surface. The surrounding fishes started to bite the sea star, feeding on its tube feet. There were about five commensal porcelain crabs (Minyocerus angustus; up to $6 \mathrm{~mm}$ TL), living associated to the sea star's oral surface, between its tube feet. One crab was taken and when it was left $30 \mathrm{~cm}$ above the bottom in the water column, a sand perch approached and preyed on the crab.

During all field observations on which an individual of $L$. senegalensis engaged in feeding activities and moving was spotted, there were sand perches or aquavinas surrounding or following it. The followed $L$. senegalensis individuals measured about $150-220 \mathrm{~mm}$ radius, and following generally lasted less than a minute, except for the last record involving a large group of $D$. formosum individuals and manipulation, with about 50 min of feeding activities (including following and other feeding such as preying on tube feet of the sea star).

Diet analysis of 20 individuals of the sand perch (37-170 $\mathrm{mm} \mathrm{SL}$ ), and 30 of the aquavina ones (53-202 mm SL) showed, in decreasing order of frequency of occurrence (see Bowen, 1992), $91.7 \%$ crustaceans (mostly shrimps with $84 \%$ of crustaceans items), $45.8 \%$ fishes, $17.7 \%$ molluscs, $6.2 \%$ brittle stars, and $3.1 \%$ polychaete worms. Mostly preyed sea basses items were benthic, including infauna forms.

Diplectrum formosum and $D$. radiale are similar, small serranids (up to $300 \mathrm{~mm}$ TL) that inhabit soft bottoms such as sand and mud (Figueiredo \& Menezes, 1980; Humann, 1994). These bottom types also frequently harbor the sea star L. senegalensis, which burrows itself to feed on infauna and benthic prey (such as clams) and is rarely seen in the open (Humann, 1993; Monteiro \& Pardo, 1994). The presence of infauna prey items in sand perches and aquavinas diets may be related to the feeding association reported herein, as not one individual of Diplectrum was observed ingesting mouthfuls of substrate, nor digging the bottom searching for prey during a two-year study on their feeding habits (FZG unpublished M.Sc. thesis). Sand perches and nine-armed sea stars do not overlap in its food requirements, as the latter feeds mostly on clams (Monteiro \& Pardo, 1994), and the fishes feed mostly on shrimps (this paper). 


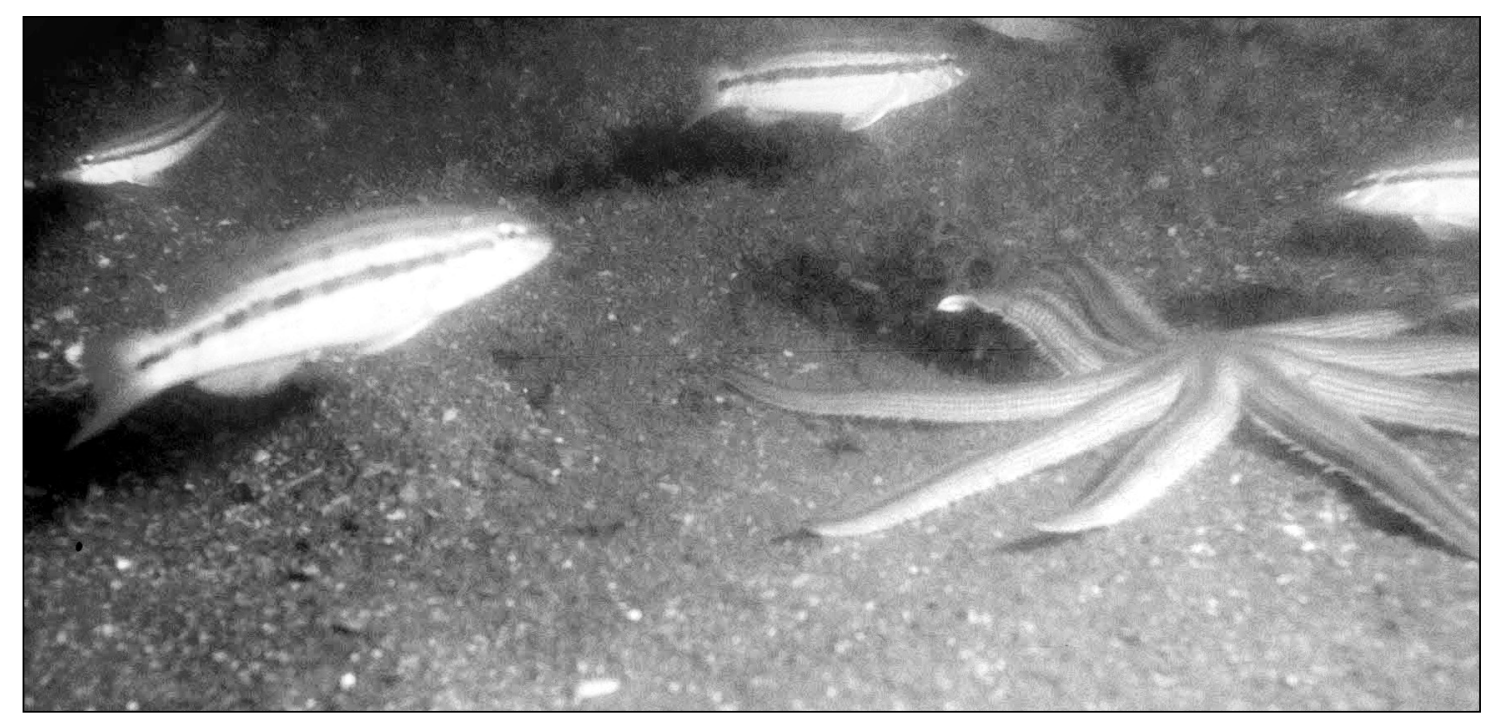

Fig. 1 - Three adult Diplectrum formosum (about $130 \mathrm{~mm} \mathrm{SL}$ ), following a sea star Luidia senegalensis, while a juvenile D. formosum inspects the substrate (upper left) (photo H. F. dos Santos).

Thus, in agreement with previous studies on following behaviour, this association benefits the followers, which gain access to otherwise unavailable prey (see Diamant \& Shpigel, 1985; Strand, 1988). The bites aimed at the $L$. senegalensis aboral surface perhaps were keeping the sea star moving, a behaviour likely similar to the "rubbing" of eels by groupers (Dubin, 1982). Sea star tube feet and its commensal porcelain crabs showed to be potential prey to the two Diplectrum species, but under normal conditions, this food type should be inaccessible (most likely the fishes are unable to overturn the sea star by themselves). However, if the sea star is overturned by a larger predator, or when it is sick and weak, and may be turned without much effort, the sand perches may take the opportunity to exploit this unusual food source.

Groupers are inquisitive fishes (Diamant \& Shpigel, 1985; Humann, 1994), and species of Diplectrum tit to this pattern (pers. obs.). Serranids are visually oriented predators alert to every moving thing nearby, and following probably derived from this inquisitive behaviour and learning ability (see also Diamant \& Shpigel, 1985). Strand (1988) pointed out that "the variety of heterospecifics foraging associations and the extent to which reef predators employ heterospecifics, and even members of other phyla illustrates the interdependence of reef dwellers and the general plasticity of behaviour among predators". On Fernando de Noronha Archipelago, northeastern Brazil, three individuals of the coney serranid Cephalopholis fulva (about $200 \mathrm{~mm}$ TL) were recorded at daytime following a large brittle star, Ophioderma sp. (about $350 \mathrm{~mm}$ radius) on a rock and sand bottom (I. Sazima, pers. comm.). Following associations between bottom-dwelling invertebrates and serranids are probably more widely distributed than presently thought. Sandy and muddy bottoms are promising habitats for this kind of association, due to their harboring of a large array of sea stars, brittle stars, and other bottom disturbing organisms such as spider crabs. Further field observations will most likely disclose additional interspecific feeding associations between serranids and invertebrate nuclear predators.

Acknowledgments - This report is a part of my M.Sc. thesis on feeding habits of four sympatric serranid species. I thank A. L. A. Melo, A. C. Ribeiro, H. F. dos Santos, and L. S. F. Martins, for fieldwork help; R. M. C. Castro for advise in my M.Sc. thesis and suggestions on manuscript; I. Sazima and J. P. Barreiros for useful suggestions on the manuscript; F. L. M. Mantelatto for help with crustaceans identification; CEBIMar and FFCLRP-USP for logistical support; IBAMA for collecting permit (DIREN 033/98); FAPESP (grant 98/ 10340-1), for essential financial support. 


\section{REFERENCES}

BOWEN, S. H., 1992, Quantitative description of the diet, pp. 325-336. In: L. A. Nielsen \& D. L. Johnson (eds.), Fisheries techniques. American Fisheries Society, Blacksburg, 468p.

DIAMANT, A. \& SHPIGEL, M., 1985, Interspecific feeding associations of groupers (Teleostei: Serranidae) with octopuses and moray eels in the Gulf of Eilat (Aqaba). Env. Biol. Fish., 13(2): 153-159.

DUBIN, R. E., 1982, Behavioral interactions between Caribbean reef fish and eels (Muraenidae and Ophichthidae). Copeia, 1982(1): 229-232.

FIGUEIREDO, J. L. \& MENEZES, N. A., 1980, Manual de peixes marinhos do Sudeste do Brasil. III. Teleostei (2). Museu de Zoologia, Universidade de São Paulo, São Paulo, 90p.

GIBRAN, F. Z. \& CASTRO, R. M. C., 1999, Activity, feeding behaviour and diet of Ogcocephalus vespertilio in southern west Atlantic. J. Fish Biol., 55: 588-595.

HOBSON, E. S. \& CHESS, J. R., 1986, Relationships among fishes and their prey in a nearshore sand community of southern California. Env. Biol. Fish., 17: 201-226.
HUMANN, P., 1993, Reef creature identification: Florida, Caribbean, Bahamas. New World Publications, Inc., Florida, 320p.

HUMANN, P., 1994, Reef fish identification: Florida, Caribbean, Bahamas, 2nd ed. Vaughan Press, Orlando, $396 \mathrm{p}$.

KARPLUS, I., 1978, A feeding association between the grouper Epinephelus fasciatus and the moray eel Gymnothorax griseus. Copeia, 1978: 164.

MONTEIRO, A. M. G. \& PARDO, E. V., 1994, Dieta alimentar de Astropecten marginatus e Luidia senegalensis (Echinodermata-Asteroidea). Rev. Brasil. Biol., 54(1): 49-54.

SAZIMA, I., 1986, Similarities in feeding behaviour between some marine and freshwater fishes in two tropical communities. J. Fish Biol., 29: 53-65.

STRAND, S., 1988, Following behavior: interspecific foraging associations among Gulf of California reef fishes. Copeia, 1988(2): 351-357.

ZAHORCSAK, P., SILVANO, R. A. M. \& SAZIMA, I., 2000, Feeding biology of a guild of benthivorous fishes in a sandy shore on south-eastern Brazilian coast. Rev. Brasil. Biol., 60: 511-518. 